\title{
COVID-19 related acute respiratory distress syndrome: Pathological, radiological and clinical concordance
}

\author{
Fatma YILDIRIM $^{\mathbf{1}}(\mathrm{ID})$ \\ PInar YILDIZ \\ GÜLHAN $^{2}$ (ID) \\ Meltem ŞiMŞEK ${ }^{3}(I D)$
}

${ }^{1}$ Clinic of Pulmonary Medicine, COVID Intensive Care Unit, Diskapi Yildirim Beyazit Research and Education Hospital, University of Health Science, Ankara, Turkey

1 Sağıık Bilimleri Üniversitesi, Dışkapı Yıldırım Beyazıt Araştırma ve Eğitim Hastanesi, Göğüs Hastalıkları Kliniği, COVID Yoğun Bakım Ünitesi, Ankara, Türkiye

2 Department of Pulmonary Medicine, Düzce University Faculty of Medicine, Düzce, Turkey

${ }^{2}$ Düzce Üniversitesi Tıp Fakültesi, Göğüs Hastalıkları Anabilim Dalı, Düzce, Türkiye

${ }^{3}$ Clinic of Internal Medicine, COVID Intensive Care Unit, Diskapi Yildirim Beyazit Research and Education Hospital, University of Health Science, Ankara, Turkey

3 Sağlık Bilimleri Üniversitesi, Dışkapı Yıldırım Beyazıt Araştırma ve Ĕgitim Hastanesi, Dahiliye Kliniği, COVID Yoğun Bakım Ünitesi, Ankara, Türkiye
Cite this article as: Yıldırım F, Yıldız Gülhan P, şimşek M. COVID-19 and thrombosis: COVID-19 related acute respiratory distress syndrome: Pathological, radiological and clinical concordance. Tuberk Toraks 2021;69(3):360-368.

\section{Address for Correspondence (Yazışma Adresi)}

\section{Dr. Pınar YILDIZ GÜLHAN}

Department of Pulmonary Medicine, Düzce University Faculty of Medicine, DÜZCE - TURKEY

e-mail: pinaryildiz691@hotmail.com

CCopyright 2021 by Tuberculosis and Thorax. Available on-line at www.tuberktoraks.org.com

\section{ABSTRACT}

COVID-19 related acute respiratory distress syndrome: Pathological, radiological and clinical concordance

Severe coronavirus 2019 disease (COVID-19) represents viral pneumonia from severe acute respiratory syndrome coronavirus 2 (SARS-CoV-2) infection leading to acute respiratory distress syndrome (ARDS). However, when ARDS occurs as part of COVID-19, it has different features. The strategy of breathing support is very important in treating COVID-19 related ARDS (CARDS). Though it meets the CARDS Berlin definition, COVID-19 pneumonia is a specific disease with different phenotypes. Recently, it has been suggested that CARDS has two phenotypes, type L (Type 1 or non-ARDS) and type $H$ (Type 2, ARDS), and these phenotypes respond differently to respiratory support treatments. In this review, after mentioning the pathophysiology and radiological relationship of CARDS, the definition and treatment approaches of two different forms of CARDS were discussed.

Key words: Severe acute respiratory syndrome coronavirus 2 (SARS-CoV-2); severe coronavirus 2019 disease; (COVID-19 related ARDS; COVID-19), phenotypes 


\section{Öz}

\section{COVID-19 ilişkili akut solunum sıkıntısı sendromu: Patolojik, radyolojik ve klinik durum}

A ̆̆ır koronavirüs 2019 hastalığı (COVID-19), akut solunum sıkıntısı sendromuna (ARDS) yol açan ağır akut solunumsal sendrom koronavirüs 2 (SARS-CoV-2) enfeksiyonundan kaynaklanan viral pnömoniyi temsil eder. Ancak ARDS, COVID-19'un bir parçası olarak ortaya çıktığında farklı özellikler göstermektedir. Solunum destek tedavi stratejileri, COVID-19 ilişkili ARDS (CARDS) tedavisinde çok önemlidir. CARDS Berlin tanımını karşılasa da COVID-19 pnömonisi farklı fenotiplere sahip spesifik bir hastalıktır. Son zamanlarda, CARDS'In tip L (Tip 1 veya ARDS olmayan) ve tip H (Tip 2, ARDS) olmak üzere iki fenotipe sahip olduğu ve bu fenotiplerin solunum destek tedavilerine farklı yanıt verdiği öne sürülmüştür. Bu derlemede, CARDS'ın patofizyolojisi ve radyolojik ilişkisinden bahsedildikten sonra iki farklı CARDS formunun tanımı ve tedavi yaklaşımları tartışılmıştır.

Anahtar kelimeler: Ă̆ır akut solunumsal sendrom koronavirüs 2 (SARS-CoV-2); ağır koronavirüs 2019 hastalığı (COVID-19); COVID19 ilişkili ARDS; fenotipler

\section{INTRODUCTION}

Although the new type of severe acute respiratory syndrome coronavirus 2 (SARS-CoV-2) associated with acute respiratory distress syndrome (ARDS) meets the Berlin 2012 ARDS definition, it seems to be a disease with different phenotypes. The most important feature of the coronavirus 2019 disease (COVID19)-associated ARDS (CARDS), which differs from classic ARDS, is that the respiratory mechanics of patients have been preserved despite severe hypoxaemia. Patients with different respiratory system compliance (CRS) may experience hypoxaemia with similar severity. The patients do not seem to exhibit high minute ventilation, tachypnoea and dyspnoea. It has been suggested that classifying the patients into type $\mathrm{L}$ (type 1 , non-ARDS) and type $\mathrm{H}$ (type 2, ARDS type) can help both in determining the patients' prognosis and in selecting the respiratory support therapies to be applied $(1,2)$. Type $L$ and type $H$ patients are differentiated by thoracic computed tomography (CT) findings at the time of admission. Initially, the infiltrations are limited and generally of ground-glass density suggesting interstitial oedema rather than alveolar oedema, later transforming into alveolar consolidations. These two patient groups also differ in terms of CRS and responses to positive end-expiratory pressure (PEEP) (3). In this review, it was aimed to mention the pathophysiology and radiological relationship of CARDS and then discuss the definition and treatment approaches of the two different forms of CARDS.

\section{COVID-19-Associated Acute Respiratory Distress Syndrome}

The SARS-CoV-2 outbreak, which first appeared in Wuhan, China, in December 2019, has turned into a pandemic and caused unprecedented pressure on health systems globally. While most patients experienced the disease with symptoms such as mild fever and fatigue, $8 \%-32 \%$ of the patients who had to be hospitalised and treated required intensive care unit (ICU) admission $(4,5)$. Although it varies depending on the intensive care acceptance criteria of the countries and available resources, ICU mortality is reported to be between $34 \%$ and $50 \%$ worldwide $(6,7)$. At the beginning of the COVID-19 pandemic, priority was initially given to increasing the number of ICU beds and ventilators and employment of intensive care professionals worldwide. Lung-protective mechanical ventilation (MV) strategies, high PEEP and prone position, which form the basis of classical ARDS treatment, were used in the management of COVID-19-associated patients with ARDS. However, it was later observed that mortality and morbidity were high in these patients who underwent classical ARDS treatment protocols. The compliance of lung systems was different in these patient groups, as well as their response to classical ARDS treatments. Patient groups with radiological images that correlated with the pathophysiology had different lung compliance and responses to treatment (1-7).

\section{Pathological Findings of COVID-19 ARDS}

Information on the pathophysiology of COVID-19 is scattered and mostly based on post-mortem biopsies in a few patients. Although autopsy data are limited, the findings are similar to those in the H1N1 and SARS outbreaks. The rough appearance of the COVID19 lung is non-specific. The lungs are severe, with bilateral interstitial oedema and congestion. Surface areas include flesh-coloured consolidations and/or areas with diffuse bleeding. Wichmann et al. (8) and Menter et al. (9) have found visible pulmonary embolisms in one-third of patients in their studies and reported strange, scattered appearances in the gross 
Table 1. Radiological stages of COVID-19 associated ARDS and clinical concordance

\begin{tabular}{|c|c|c|}
\hline Phases & Clinical Findings & Determinat Radiological Apperances \\
\hline Very early phase & $\begin{array}{l}\text { No any symptom or only nasopharyngeal } \\
\text { swab RT-PCR positive }\end{array}$ & $\begin{array}{c}\text { Single, double or scattered focal ground-glass } \\
\text { opacities }\end{array}$ \\
\hline Early phase & $\begin{array}{l}1-3 \text { days after the onset of symptoms } \\
\text { such as fever, myalgia, headache, cough }\end{array}$ & $\begin{array}{c}\text { Interlobular septal thickenings, ground glass } \\
\text { opacities }\end{array}$ \\
\hline Rapid progression phase & Hypoxemic respiratory failure & $\begin{array}{c}\text { Vascular enlargement, consolidation areas with } \\
\text { large-white air bronchograms }\end{array}$ \\
\hline Consolidation phase & Hypoxemic respiratory failure & Multiple scattered consolidations \\
\hline Skipping phase & $\begin{array}{c}\text { 2-3 after the on set of clinical symptoms } \\
\text { with/without hypoxemia }\end{array}$ & $\begin{array}{l}\text { Interlobular septal thickening, small amount of } \\
\text { scattered consolidations }\end{array}$ \\
\hline
\end{tabular}

sections of the lung parenchyma. Pleural adhesions were also found on one autopsy. The microscopic pathological findings of COVID-19 are also non-specific. No specific pathognomonic findings for COVID19 have been found. The most frequently reported pathological finding in fatal cases is diffuse alveolar damage (DAD). Findings have been reported in both acute (exudative) and organised (fibroproliferative) phases $(10,11)$. The direct occurrence of DAD without MV application suggests that it is caused by direct viral damage rather than ventilator lung injury or oxygen toxicity.

In the acute phase, CARDS is characterised by hyaline membrane formations as in classical ARDS. There are varying degrees of fibroblast and myofibroblast proliferation in the organised phase. CARDS cannot be distinguished morphologically from other causes of DAD. There is type 2 pneumocyte proliferation prominently. Cytomegaly, nucleomegaly and dominantly eosinophilic nuclei are observed in these cells, which can be seen in many infectious and non-infectious conditions of DAD. No definite and pathognomonic cytopathological findings were found for COVID-19. Capillary congestion and suppurative pneumonia have been found in all 21 specimens in Menter et al.'s study (9). Similar pathologies have also been described in the interstitium. Patchy infiltrates consisting mainly of lymphocytes were found in alveolar septa. Focal neutrophil collections seen in acute bronchopneumonia were also observed, as well as mixed cells of CD4+ and CD8+ lymphocytes (8-11).

\section{Radiological Images of COVID-19 ARDS}

Radiological findings in patients with COVID-19 can also be categorised into five stages that show compatibility and correlation with pathological stages. In asymptomatic or nasopharyngeal swab RT-PCR- positive patients, single, double or scattered focal ground-glass opacities, nodules in the central lobule, surrounding frosted glass opacities, diffuse consolidations and air bronchograms can be seen on thorax CT at the very early stage. Congestion in the alveolar septal capillaries, dilatation, fluid exudation into the alveolar cavity and interlobular interstitial oedema can be seen in the early stage 1-3 days after the onset of clinical findings. The rapid progression phase, 3-7 days after clinical onset, in which patients mostly have hypoxaemic respiratory failure and are diagnosed with CARDS according to PEEP application, is characterised by the accumulation of massive exudative fluid in the alveoli. Vascular enlargement, exudative fluid discharge into the interstitium and consolidation areas with large, white air bronchograms are seen. In the consolidation phase 7-14 days after clinical onset, multiple scattered consolidations arising from fibrous exudates are observed in the alveolar space. In the skipping phase 2-3 weeks after clinical onset, interlobular septal thickening, bending of the bronchial walls such as strands and a small amount of scattered consolidations can be seen (12). The radiological stages of a patient with COVID-19 are summarised in Table 1 and shown in Figure 1.

In COVID-19, acute hypoxaemic respiratory failure occurs as a result of interstitial oedema, impairment in pulmonary perfusion and decreased compliance in ventilated lung areas, leading to ARDS (13). Microand macro-thrombi formed in the pulmonary vascular bed, increase in venous blood mixture, pulmonary vasoconstriction due to hypoxaemia and dead space respiration increase the amount of shunt (14). This shunt determines the severity of hypoxaemia especially in type $\mathrm{L}$ patients described by Gattinoni et al. (1) (Figure 2). 
Yıldırım F, Yıldız Gülhan P, Şimşek M.

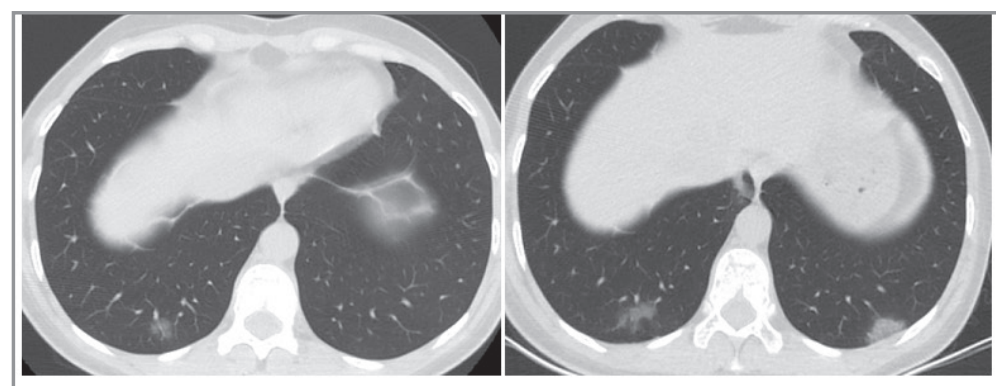

\section{Very Early Phase}

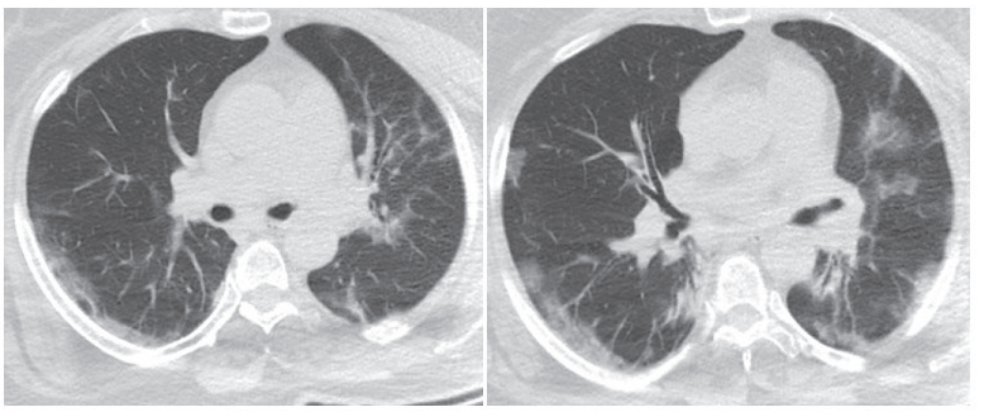

\section{Early Phase}
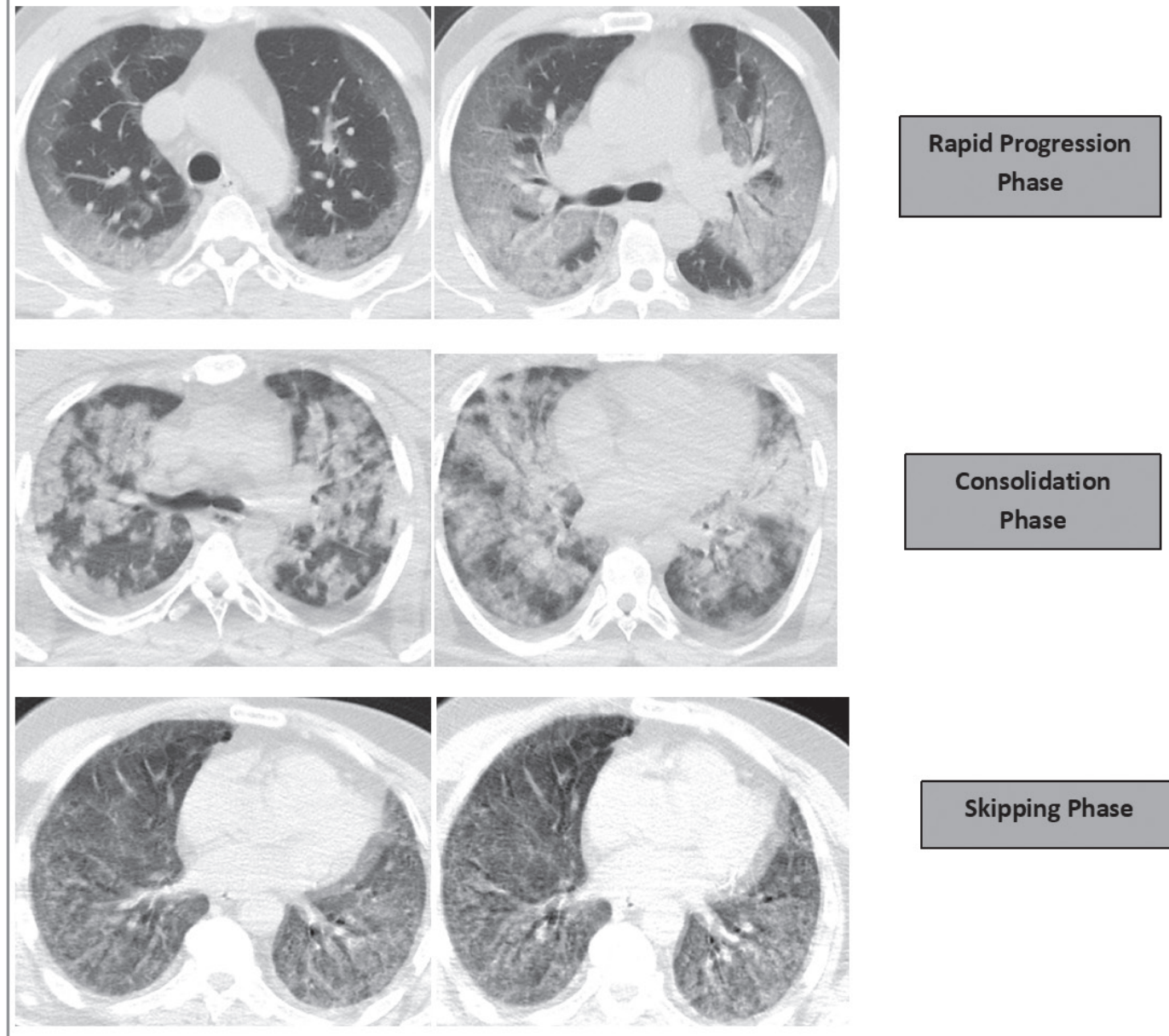

Skipping Phase

Figure 1. Thorax computed tomography findings of a patient diagnosed with CARDS with a positive SARS-CoV-2 real-time PCR. from the clinical baseline to the recovery phase. 


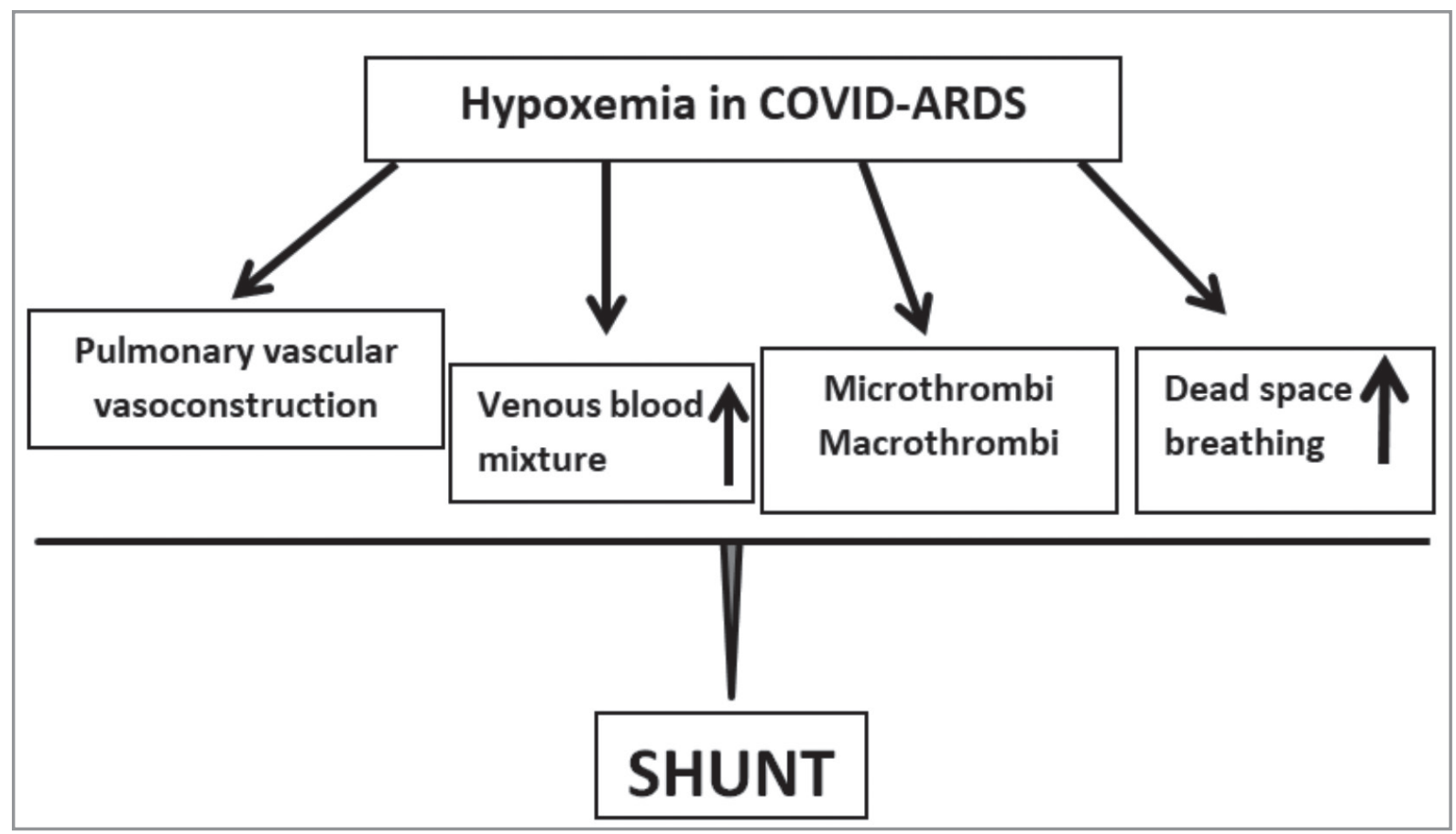

Figure 2. COVID-19 ARDS pathophysiological mechanism of hypoxemia especially in type L patients.

\section{Type L CARDS (Type 1 or Non-ARDS)}

When respiratory failure occurs due to COVID-19 pneumonia, although there is poor oxygenation, patients' lung compliance is relatively preserved. Characteristically, minute ventilation is high. Involvement in thoracic CT is limited, and groundglass opacities are initially observed reflecting interstitial oedema rather than alveolar oedema. Patients with this clinical and radiological phenotype do not appear to have tachypnoea and dyspnoea. This group of patients, defined as type L or type 1 CARDS by Gattinoni et al. (1), includes patients with isolated viral pneumonia with near-normal lung compliance. In many patients, the disease can remain at this stage, and clinical recovery occurs without worsening of respiratory symptoms. Although patients have severe hypoxaemia, generally, CRS is above $50 \mathrm{ml} / \mathrm{H}_{2} \mathrm{O}$. Lung air volume is relatively preserved, and recurrent lung air spaces are few. The main mechanism of hypoxaemia in this group is pulmonary vasoconstriction due to hypoxaemia and ventilation/perfusion (V/Q) mismatch resulting from impaired pulmonary blood flow. In this patient group, high PEEP and prone position restore oxygenation by improving the $\mathrm{V} / \mathrm{Q}$ ratio by rearranging the distribution of pulmonary blood flow, not by opening the closed alveoli as in classical ARDS. In type L patients, there are less lung areas that can be seen on thoracic CT and a higher right/left venous mixing ratio (15) (Figure 3A).

\section{Type H CARDS (Type 2 or ARDS)}

If lung pathology progresses due to the severity of the COVID-19 (viral load), excessive immune response of the patient or the suboptimal management of the disease, inappropriate lung ventilation lung could lead to type H CARDS, characterised by reduced ventilated lung areas. Some patients have diffuse alveolar consolidations in thorax CT, similar to the clinical phenotype of classical ARDS. In this group of patients with CARDS admitted to the ICU due to respiratory failure, the lung compliance of $20 \%-30 \%$ of patients with severe hypoxaemia is below $40 \mathrm{ml} /$ $\mathrm{H}_{2} \mathrm{O}$. Low lung compliance decreases the ventilated lung areas and increases the areas that can be recruited. Some of these hypoxic patients receive non-invasive mechanical ventilation (NIMV) before admission to the ICU. Patients with high respiratory effort and strong respiratory drive present with very high negative intrathoracic pressures. For this reason, they also encounter self-inflicted lung injury (SILI) and lung damage caused by NIMV in addition to the damage caused by viral pneumonia $(1,15,16)$ (Figure $3 b$ ). 


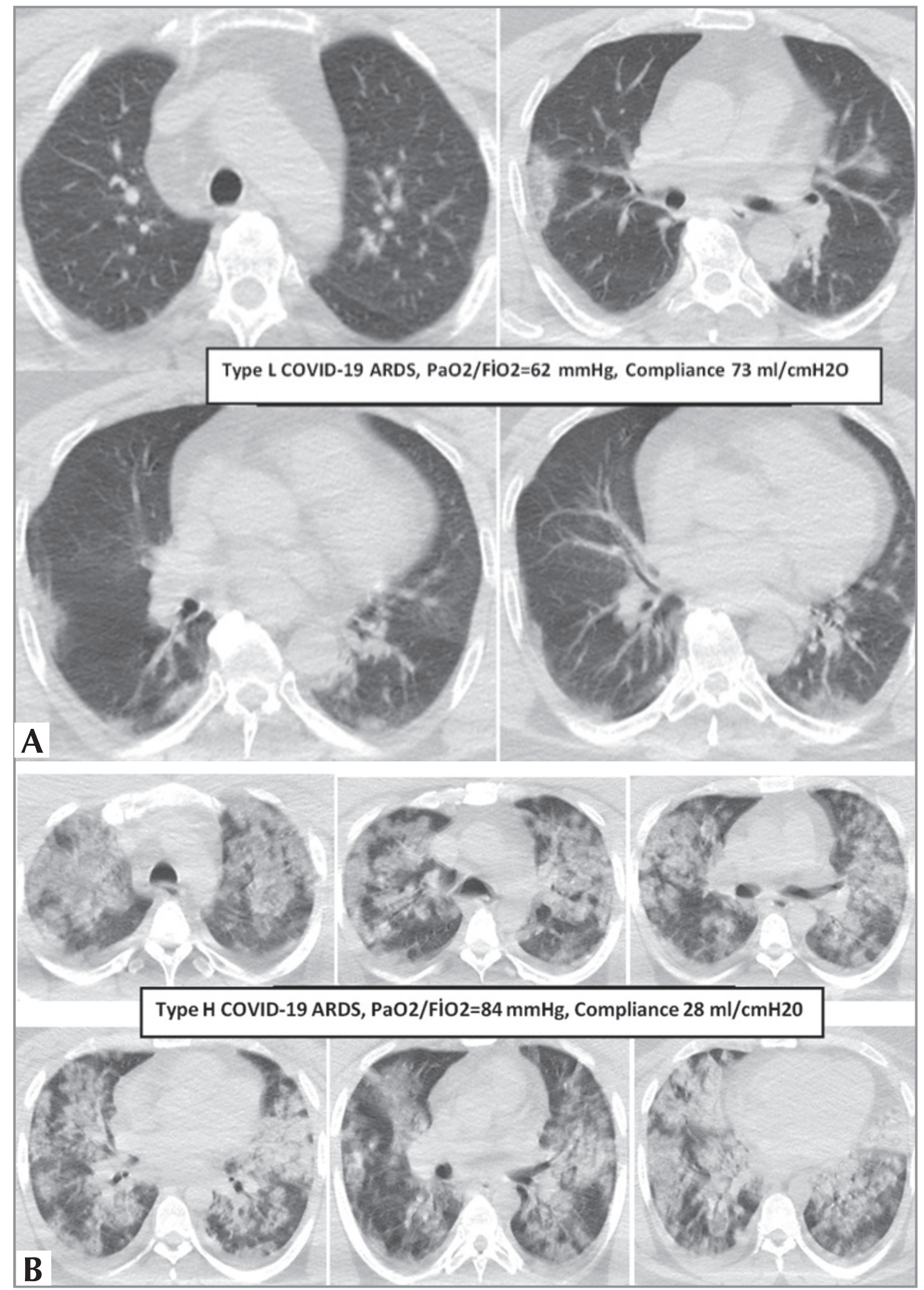

Figure 3. A. Thorax computed tomographic findings of Type L COVID-19 associated ARDS, B. Thorax computed tomographic findings of type H COVID-19 associated ARDS. 
Table 2. Mechanical ventilation approaches in CARDS patients

\begin{tabular}{|c|c|c|}
\hline Before Intubation & During Mechanical Ventilation & Weaning Process \\
\hline Type L and Type H CARDS & Type L and Type H CARDS & Type L and Type H CARDS \\
\hline \multirow[t]{3}{*}{$\begin{array}{l}\text { Goal: Sufficient gas exchange, } \\
\text { reduction of tachypnea }\end{array}$} & $\begin{array}{l}\text { Transpulmonary and vascular pressures } \\
\text { should be minimized to avoid VILI. }\end{array}$ & $\begin{array}{l}\text { Transitions during weaning should be done } \\
\text { carefully. }\end{array}$ \\
\hline & $\begin{array}{l}\text { PEEP, frequency and tidal volume should } \\
\text { should be adjusted for acceptable gas } \\
\text { exchange. }\end{array}$ & $\begin{array}{l}\text { Sudden changes should be avoided, } \\
\text { spontaneous breathing trials should only be } \\
\text { done at the end of the weaning process. }\end{array}$ \\
\hline & Negative fluid balance must be preserved. & \\
\hline \multirow{2}{*}{$\begin{array}{l}\text { Respiratory support therapies: } \\
\text { Oxygen therapy, CPAP, NIMV, } \\
\text { HFNO, Awake prone position }\end{array}$} & $\begin{array}{c}\text { Type L: Use lower PEEP }\left(<10 \mathrm{~cm} \mathrm{H}_{2} \mathrm{O}\right) \text {, use } \\
\text { higher tidal volume }(7-9 \mathrm{ml} / \mathrm{kg})\end{array}$ & \\
\hline & $\begin{array}{l}\text { Reduce oxygen requirement } \\
\text { Consider prone position }\end{array}$ & \\
\hline \multirow{3}{*}{$\begin{array}{l}\text { Rational: Avoid SILI because } \\
\text { Strong breathing effort can cause } \\
\text { lung stress }\end{array}$} & $\begin{array}{l}\text { Type H: Use higher PEEP }\left(<15 \mathrm{~cm} \mathrm{H}_{2} \mathrm{O}\right) \\
\text { Lower tidal volume }(5-6 \mathrm{ml} / \mathrm{kg})\end{array}$ & \\
\hline & Reduce oxygen requirement & \\
\hline & Apply prone position (at least 12 hours/day) & \\
\hline
\end{tabular}

\section{Treatment of COVID-19 ARDS}

\section{Non-invasive mechanical ventilation applications in patients with COVID-19}

While applying NIMV and continuous positive airway pressure (CPAP) to non-intubated patients before ICU admission, they should be carefully evaluated in terms of the two phenotypes. NIMV and CPAP can be applied in wards and in the emergency room, as they improve oxygenation in patients with lungs that may have recruitment potential. The patient's respiratory and inspiratory effort must be considered. The most ideal and objective way to measure patients' respiratory effort is to measure the transpulmonary pressure (TP $=$ alveolar pressure-pleural pressure) by placing an oesophageal catheter and detecting the shifts in pressure. An oesophageal pressure above $15 \mathrm{~cm} \mathrm{H}_{2} \mathrm{O}$ causes high risk of damage to patients' lungs (SILI) by producing high tidal volumes. These patients should be intubated and mechanically ventilated in a controlled mode. However, TP measurement cannot be performed in several centres. Therefore, clinical signs of respiratory effort should be routinely and carefully checked. Endotracheal intubation should be considered in the presence of respiratory distress. Deterioration of patients from type $\mathrm{L}$ to type $\mathrm{H}$ with SILI should be prevented $(15,16)$.

\section{Management of intubated patients with COVID-19 ARDS}

\section{A. Tidal volume and PEEP application}

Type $L$ patients with a higher tidal volume $(6 \mathrm{ml} /$ ideal body weight [IBW]) and respiratory rate of 15-20 breaths per minute should be placed on MV. More liberal tidal volumes $(7-8 \mathrm{ml} / \mathrm{IBW})$ can be considered to correct the patient's dyspnoea and hypercapnia. Also, higher PEEP can be utilised, but it should be limited to 8-10 $\mathrm{cm} \mathrm{H}_{2} \mathrm{O}$. Higher PEEP values may decrease pulmonary compliance and impair right heart functions. Lung-protective MV strategies should be applied in type $\mathrm{H}$ patients, as in classical ARDS with low tidal volume and low partial pressure. Cautiously increasing PEEP to $14-15 \mathrm{~cm} \mathrm{H}_{2} \mathrm{O}$ may correct oxygenation. In this process, the decrease in central venous oxygen saturation $\left(\mathrm{ScVO}_{2}\right)$ may indicate a decrease in cardiac output due to high PEEP. Cardiac output monitoring with echocardiography may be beneficial in high PEEP (17). Respiratory support treatments and MV application methodology and weaning that should be applied in type $L$ and type $\mathrm{H}$ patients are summarised in Table 2 .

\section{B. Prone position}

In patients with classical ARDS, prone positioning should favour the re-expansion of the collapsed lung 
parenchyma in dorsal lung regions and reduction in aeration in ventral ones, leading to both lung recruitment and more homogenous lung aeration. While ventilation distribution is certainly influenced by postural change, lung perfusion is usually considered less dependent on gravity. In type L CARDS patients, the prone position should be applied as a salvage therapy manoeuvre. In these patients with CARDS and high lung compliance and low recruitable lung areas, the prone position does not open the closed alveoli by removing the weight of the heart and mediastinum as seen in classical ARDS patients. Its effect on oxygenation is through redistribution of the pulmonary blood flow. Although the benefit of longterm supine/prone cycles is less efficient in patients with high lung compliance, it can create stress and workload on the patient and the healthcare team. In type $\mathrm{H}$ patients, the prone position should be applied for a longer time (at least $12 \mathrm{~h} /$ day) as part of the treatment in patients with severe ARDS $(1,17)$.

The recruitability of the lungs of patients with CARDS is unpredictable, unlike those in classical ARDS. Although phenotyping and special MV strategies are recommended based on thoracic CT and clinical findings, data on respiratory mechanics of patients with CARDS are limited. Beloncle et al. (18) measured airway opening pressure (AOP) by inflating with PEEP $5 \mathrm{~cm} \mathrm{H}_{2} \mathrm{O}$ at low flow $(5 \mathrm{~L} / \mathrm{min}$; tidal volume $=9 \mathrm{ml} / \mathrm{IBW})$. In the pressure-time curve, AOP was measured from the ventilator. The recruitment/ inflation $(R / I)$ ratio is the difference between the recruited lung volume (baby lung). A high $\mathrm{R} / \mathrm{I}$ ratio (above 0.5 ) indicates recruitability. R/I ratio was evaluated on the first day of MV in 25 patients and on the fifth day in 15 patients. Sixteen (64\%) patients were evaluated with a high probability of recruitment $(R / I=$ $0.7 ; 0.55-0.94)$, and nine (36\%) patients had a low probability of recruitment $(\mathrm{R} / \mathrm{l}=0.4 ; 0.31-0.48)$. When the patients were re-evaluated on the fifth day, it was found that the lungs of seven patients were still recruiting; the recruitment potential of three patients decreased. The $\mathrm{PaO}_{2} / \mathrm{FIO}_{2}$ ratio was higher in the group with $15 \mathrm{~cm} \mathrm{H} 2 \mathrm{O} P E E P$ than that in the group with $5 \mathrm{~cm} \mathrm{H} \mathrm{H}_{2} \mathrm{O}$ PEEP with high recruitment capacity $(173 \mathrm{mmHg}$ vs. $135 \mathrm{mmHg} ; \mathrm{p}<0.01)$. There was no difference in the $\mathrm{PaO}_{2} / \mathrm{FIO}_{2}$ ratio in the two PEEP values in the group with low recruitment capacity (122 mmHg vs. $137 \mathrm{mmHg} ; \mathrm{p}=0.06$ ). The increase in the $\mathrm{PaO}_{2} / \mathrm{FIO}_{2}$ ratio was over $20 \%$ in $12(75 \%)$ patients. In both groups, the shunt fraction was found to be lower at $15 \mathrm{~cm} \mathrm{H}_{2} \mathrm{O}$ PEEP. In the case of CRS, no difference was observed between the groups in both PEEP values. In group with $15 \mathrm{~cm} \mathrm{H}_{2} \mathrm{O}$ PEEP, a high recruitment capacity was observed in the 45 (38-58) $\mathrm{ml} / \mathrm{cm} \mathrm{H}_{2} \mathrm{O}$ group, whereas a low recruitment capacity was observed in the 45 (34-53) $\mathrm{ml} / \mathrm{cm}$ $\mathrm{H}_{2} \mathrm{O}$ group $(\mathrm{p}=0.67)$. In this study, the relatively static CRS was preserved in patients with CARDS, and the recruitment potential could be predicted based on the R/I ratio measured after intubation (18).

\section{CONCLUSION}

COVID-19 is a systemic disease that mainly causes endothelial damage. When the disease and respiratory failure are not managed in conscious hands, the patient may progress to ARDS. Each CARDS phenotype should be carefully determined, and the appropriate treatment modality for NIMV or invasive MV should be carefully applied. As in classical ARDS, alveolar recruitment response to PEEP is unpredictable in CARDS.

\section{REFERENCES}

1. Gattinoni L, Chiumello D, Caironi P, Busana M, Romitti F, Brazzi L et al. COVID-19 pneumonia: different respiratory treatments for different phenotypes? Intensive Care Med 2020; 46(6): 1099-102.

2. Gattinoni L, Coppola S, Cressoni M, Busana M, Rossi S, Chiumello D. COVID-19 does not lead to a "typical" acute respiratory distress syndrome. Am J Respir Crit Care Med 2020; 201(10): 1299-300.

3. Li X, Ma X. Acute respiratory failure in COVID-19: is it "typical" ARDS? Crit Care 2020; 24(1): 198.

4. Grasselli G, Zangrillo A, Zanella A, Antonelli M, Cabrini L, Castelli $A$ et al. Baseline characteristics and outcomes of 1591 patients infected with SARS-CoV-2 admitted to ICUs of the Lombardy region, Italy. JAMA 2020; 323(16): 157481 .

5. Arentz M, Yim E, Klaff L, Lokhandwala S, Riedo FX, Chong $M$, et al. Characteristics and outcomes of 21 critically ill patients with COVID-19 in Washington State. JAMA 2020; 323(16): 1612-4.

6. Jiang F, Deng L, Zhang L, Cai Y, Cheung CW, Xia Z. Review of the clinical Characteristics of Coronavirus Disease 2019 (COVID19). J Gen Intern Med 2020; 35(5): 1545-49.

7. Wang D, Hu B, Hu C, Zhu F, Liu X, Zhang J, et al. Clinical characteristics of 138 hospitalized patients with 2019 Novel Coronavirus-infected pneumonia in Wuhan, China. JAMA 2020; 323(11): 1061-9. 
8. Wichmann D, Sperhake J, Lütgehetmann M, Steurer $S$, Edler C, Heinemann A, et al. Autopsy findings and venous thromboembolism in patients with COVID-19: a prospective cohort study. Diagn Pathol 2020; 15(1): 103.

9. Menter T, Haslbauer J, Nienhold R, Savic S, Hopfer H, Deigendesch $N$, et al. Post-mortem examination of COVID-19 patients reveals diffuse alveolar damage with severe capillary congestion and variegated findings of lungs and other organs suggesting vascular dysfunction. Histopathology 2020; 77(2): 198-209.

10. Tian S, Xiong Y, Liu H, Niu L, Guo J, Liao M, et al. Pathological study of the 2019 novel coronavirus disease (COVID-19) through postmortem core biopsies. Mod Pathol; 33(6): 1007-14.

11. Xu Z, Shi L, Wang Y, Zhang J, Huang L, Zhang C, et al. Pathological findings of COVID-19 associated with acute respiratory distress syndrome. Lancet Respir Med 2020; 8(4): 420-2.

12. Ye $Z$, Zhang $Y$, Wang $Y$, Huang $Z$, Song B. Chest CT manifestations of new coronavirus disease 2019 (COVID-19): a pictorial review. Eur Radiol 2020; 30(8): 4381-9.
13. Matthay MA, Zemans RL, Zimmerman GA, Arabi YM, Beitler JR, Mercat A, et al. Acute respiratory distress syndrome. Nat Rev Dis Primers 2019; 5(1): 18.

14. Batah SS, Fabro AT. Pulmonary pathology of ARDS in COVID-19: A pathological review for clinicians. Respir Med 2021; 176: 106239.

15. Marini JJ, Gattinoni L. Management of COVID-19 Respiratory Distress. JAMA 2020; 323(22): 2329-30.

16. Robba C, Battaglini D, Ball L, Patroniti N, Loconte M, Brunetti l, et al. Distinct phenotypes require distinct respiratory management strategies in severe COVID-19. Respir Physiol Neurobiol 2020; 279: 103455.

17. Navas-Blanco JR, Dudaryk R. Management of respiratory distress syndrome due to COVID-19 infection. BMC Anesthesiol 2020; 20(1): 177.

18. Beloncle FM, Pavlovsky B, Desprez C, Fage N, Olivier PY, Asfar P, et al. Recruitability and effect of PEEP in SARSCov-2-associated acute respiratory distress syndrome. Ann Intensive Care 2020; 10(1): 55. 